\title{
PENINGKATAN KETERAMPILAN MENULIS KARANGAN NARASI MELALUI MEDIA GAMBAR SERI PADA SISWA KELAS III SEMESTER 2 SDN 1 WANASABA TAHUN PELAJARAN 2015/2016
}

\author{
(THE IMPROVEMENT OF NARRATIVE WRITING SKILL TROUGH PICTURES \\ SERIES TOWARD STUDENTS OF THE SECOND SEMESTER OF THE THIRD \\ CLASS AT SDN 1 WANASABA IN ACADEMIC YEAR 2015/2016)
}

\author{
Muharipin \\ SDN 1Wanasaba, Lombok Timur \\ Pos-el: akmalwiya@gmail.com
}

Diterima: Februari 2017; Direvisi: 17 Oktober 2017; Disetujui: 23 Oktober 2017

\begin{abstract}
The study aimed at finding out the improvement of students' writing skill in class III, Semester II SDN 1 Wanasaba, academic year 2015/2016. The subject of the study is Students of class III with a total of 23 students comprised of 10 males and 13 females. The study applies two cycles. Each cycle consists of four steps, namely are planning, application, observing/evaluating, and reflecting. The method used is observation, questioner/test, and documentation. Observation conducted to observe the execution process being conducted. Questioner/test is used to find out the result of learning and achievement. Documentation is for supplement material for teaching and learning process. The result of the study shows that the achievement of Students in class III, Semester II SDN 1 wanasaba, academic year 2015/2016 in learning bahasa Indonesia on writing a simple essay based on the serial pictures using correct words and sentences choice considering spelling, capital letters, and punctuation before the application phase is very low. It is showed by the achievement of 26\%. After the application of using serial pictures, the student' achievement are better. It is showed in cycle 1, the result increases to $70 \%$ with good category. In cycle 2 , the result increases to $100 \%$ with very good category.
\end{abstract}

Keywords: skill, writing, composition, narrative

\begin{abstract}
Abstrak
Penelitian ini bertujuan untukmengetahui peningkatan keterampilan menulis siswa kelas III Semester II SDN 1 Wanasaba Tahun Pelajaran 2015/2016. Subjek penelitian ini adalah siswa kelas III semester 2 dengan jumlah siswa 23 orang yang terdiri dari laki-laki 10 orang dan perempuan 13 orang. Prosedur pelaksanaan penelitian ini terdiri atas dua siklus. Tiap siklus terdiri atasbeberapa tahapan, yaitu: perencanaan, pelaksanaan, pengamatan dan evaluasi, dan refleksi.Metode yang digunakan dalam penelitian ini adalah observasi, angket/tes dan dokumentasi. Observasi digunakan untuk mengamati jalannya proses tindakan yang dilakukan. Angket/tes digunakan untuk mengetahui hasil belajar yang dicapai. Dokumentasi digunakan untuk bahan penunjang proses pembelajaran.Hasil penelitian menunjukkan bahwa hasil belajar bahasa Indonesia materi menulis karangan narasi berdasarkan gambar seri menggunakan pilihan kata dan kalimat yang tepat dengan memperhatikan penggunaan ejaan, huruf kapital, dan tanda titik pada siswa kelas III semester 2 SDN 1 Wanasaba Tahun Pelajaran 2015/2016 sebelum dilakukan tindakan sangat rendah. Hal ini dibuktikan dengan persentase keberhasilannya mencapai26\%.Setelah dilakukan tindakan penggunaan media gambar berseri, hasil belajar tergolong sangat baik. Hal ini terbukti dengan persentase keberhasilan pada variabel hasil belajar siswa pada siklus 1 yaitu $70 \%$ dan siklus 2 adalah $100 \%$.
\end{abstract}

Kata kunci: Keterampilan, menulis, karangan, narasi 


\section{Pendahuluan}

Kompetensi mata pelajaran bahasa Indonesia terdiri atas empat aspek, yaitu keterampilan membaca, menulis, menyimak, dan berbicara. Aspek-aspek tersebut saling berkaitan dan dilaksanakan secara terpadu dengan porsi pengajaranyang seimbang dengan keterampilan bahasa lain. Keterampilan menulis lebih sulit dikuasai karena keterampilan menulis menghendaki penguasaan berbagai unsur kebahasaan dan unsur nonkebahasaan dalam penyusunan sebuah karangan atau tulisan.

Menulis merupakan suatu keterampilan berbahasa yang digunakan untuk berkomunikasi secara tidak langsung, tidak secara tatap muka dengan orang lain.

Keterampilan menulis sebagai salah satu dari empat keterampilan berbahasa mempunyai peran penting dalam kehidupan manusia. Dengan menulis, seseorang tepat mengungkapkan pikiran atau gagasan untuk mencapai maksud dan tujuan.

Tujuan pengajaran menulis di sekolah salah satunya adalah mentradisikan menulis di kalangan pelajar. Menulis digunakan untuk berkomunikasi dengan menggunakan bahasa tulis. Keterampilan menulis tidak datang dengan sendirinya. Oleh karena itu, keterampilan ini perlu dilatih secara teratur serta bersungguhsungguh.
Dalam hubungannya dengan kemampuan berbahasa, kegiatan menulis makin mempertajam kepekaan siswa terhadap kesalahan-kesalahan baik ejaan, struktur maupun tentang pemilihan kosa kata. Dilihat dari aspek menulis,tujuan pengajaran bahasa Indonesia adalah agar siswa mampu menuangkan pengalaman dan gagasan, mampu mengumpulkan perasaan secara tertulis dan jelas, mampu pula menuliskan informasi sesuai dengan pokok bahasan (konteks) dan keadaan (situasi). Keterampilan menulis merupakan suatu proses pengembangan yang menuntut pengalaman, waktu, kesempatan dan memerlukan cara berpikir yang teratur, serta mengungkapkannya dalam bentuk tulisan.

Keterampilan menulis dibagi menjadi beberapa jenis yang salah satunya berupa keterampilan menulis narasi. Keterampilan menulis narasi dibagi menjadi dua yaitu narasi ekspositoris dan narasi sugestif. Narasi ekspositoris bertujuan untuk menggugah pikiran para pembaca untuk mengetahui apa yang akan dikisahkan. Narasi sugestif pertama-tama berkaitan dengan tindakan atau perbuatan yang dirangkaikan. Kejadian itu berlangsung dalam satu kesatuan waktu (Keraf, 1987:136--138).

Pengembangan keterampilan menulis, termasuk menulis narasi, perlu mendapat perhatian yang serius sejak 
tingkat pendidikan yang paling dasar karena keterampilan menulis tidak terbentuk secara otomatis. Seseorang yang ingin terampil menulis memerlukan pengajaran dan keterampilan yang teratur, khususnya dalam menulis narasi. Seseorang dalam menulis narasi akan dituntut menggabungkan dua imajinasi dan daya nalarnya. Dengan demikian, dapat disimpulkan bahwa dengan mengembangkan keterampilan menulis narasi akan melatih kecerdasan daya pikir anak. Sebagai aspek keterampilan berbahasa, keterampilan menulis narasi dapat dimiliki oleh orang-orang yang giat dan rajin berlatih.

Berhasil tidaknya pengajaran bahasa Indonesia ditentukan beberapa faktor, di antaranya faktor siswa dan guru serta metode dalam pembelajaran yang digunakan. Menulis merupakan komponen bahasa yang paling kompleks sebab menulis melibatkan aspek pengolahan gagasan, penataan kalimat, pengembangan paragraf, pengembangan model karangan serta logika.Pelatihan menulis menuntut peran yang cukup besar bagi guru. Namun, kebanyakan guru belum begitu menyadari pentingnya pembinaan pelatihan menulis narasi tersebut sehingga kebanyakan siswa mempunyai kemampuan menulis rendah.

Upaya peningkatan keterampilan menulis narasi sebenarnya sudah banyak dilakukan oleh guru, tetapi hasil yang diperoleh kurang memuaskan karena pengajaran yang disampaikan oleh guru masih berjalan satuarah. Artinya, hanya guru yang aktif di dalam kelas, padahal, dalam proses belajar mengajar siswa diharuskan lebih aktif selama proses belajar mengajar.

Berdasarkan hasil pree test bahasa Indonesia, khususnya mengenai menulis narasai di SDN 1 Wanasaba, siswa kelas 3, dari 23 siswa yang terdiri atas 10 orang dan laki-laki dan 13 orang perempuan, keseluruhan siswa ini masih kesulitan untuk menuangkan ide dan penggunaan bahasa Indonesia yang baik dan benar. Selain itu, siswa tidak memiliki minat dan merasa jenuh untuk menulis. Hal ini dapat dilihat dari rata-rata pencapaian nilai ketuntasan dengan tingkat ketuntasan $26 \%$. Dari jumlah 23 siswa yang mendapat nilai lebih dari 75 hanya 6 siswa.

Selain hal tersebut, siswa kurang memperhatikan dan menganggap mudah pokok bahasan ini serta metode pengajaran yang digunakan guru kurang efektif. Guru belum banyak memberikan praktik dan pelatihan kepada siswa. Siswa malas menulis narasi karena pengajaran yang dilakukan guru hanya berorientasi pada teori dan pengetahuan sehingga siswa kurang berminat menulis narasi. Pada saat menulis narasi siswa hanya mementingkan panjang karangannya sehingga dalam penyusunan narasi mereka tidak 
memperhatikan penggunaan ejaan dan tanda baca, diksi, kohesi dan koherensi, serta kronologis kejadian. Usaha untuk meningkatkan keterampilan menulis narasi diperlukan suatu media pengajaran yang efektif dan efisien. Selama ini, metode ceramah dan penugasan ternyata belum mampu mencapai hasil yang optimal. Melihat kondisi demikian, peneliti tergerak untuk mengadakan penelitian untuk meningkatkan keterampilan menulis karangan narasi pada siswa kelas III SDN 1 Wanasaba tahun ajaran 2015/2016. Peneliti menerapkan media gambar seri pada pengajaran menulis karangan narasi. Melalui media ini, siswa diminta mengamati yang ada di papan tulis kemudian siswa mendiskusikan gambar dengan guru dan pada akhirnya siswa diminta menceritakan secara tertulis. Melihat keadaan yang demikian, peneliti merasa prihatin dan ingin mencari cara terbaik untuk memecahkan masalah tersebut. Salah satu cara yang peneliti tempuh adalah melakukan perbaikan pembelajaran melalui PTK dengan judul "Peningkatan Keterampilan Menulis Karangan Narasi Melalui Media Gambar Seri Pada Siswa Kelas III Semester 2 SDN 1 Wanasaba Tahun Pelajaran 2015/2016" dengan harapan keterampilan siswa dalam menulis karangan narasi meningkat.

\section{Kerangka Teori}

\subsection{Media Gambar Seri}

Dalam melakukan proses pengajaran, sering kali guru kurang mampu dalam menyampaikan ide dan maksud dari suatu materi. Tidak jarang maksud yang disampaikan guru ditangkap lain oleh siswa. Hal ini sangat mengkhawatirkan karena akan mengakibatkan tidak berhasilnya proses belajar mengajar. Untuk menangkal hal tersebut, guru dapat mempraktikkan salah satu solusi yaitu menggunakan media pengajaran. Media pengajaran berfungsi untuk memperjelas maksud dan gagasan yang disampaikan guru pada siswa atau dengan kata lain media dapat menjadi jembatan pengetahuan atara guru dan siswa.

Ditinjau dari semantiknya, gambar seri berasal dari gambar dan seri, gambar berarti tiruan barang yang berupa orang, binatang, tumbuhtumbuhan, dan sebagainya. Sedangkan seri berarti rangkaian cerita yang berturut-turut. Jadi, gambar seri berarti gambar berturut-turut. Media gambar seri disebut juga flow chart atau gambar susun. Media ini terbuat dari kertas manila berukuran lebar yang berisi beberapa gambar. Gambar tersebut berhubungan satu sama lainnya sehingga merupakan rangkaian cerita/peristiwa. Setiap gambar diberi nomor urut sesuai 
dengan urutan-urutan ceritanya

(Soeparno, 1988:18).

\subsubsection{Keunggulan dan Kelemahan}

\section{Media Gambar Seri}

Media gambar atau media grafis terdiri atas gambar, bagan diagram, grafik, poster, media dan komik. Di antara media grafis gambar adalah media yang umum dipakai.

\section{a. Keunggulan Gambar}

1) Dapat menerjemahkan ide-ide abstrak ke dalam bentuk yang lebih nyata.

2) Banyak tersedia dalam bukubuku, majalah, koran, katalog, atau kalender.

3) Gambar sangat mudah dipakai karena tidak membutuhkan peralatan.

4) Gambar tidak relatif mahal.

5) Dapat digunakan semua tingkat pengajaran dan bidang studi.

\section{b. Kelemahan Gambar}

1) Kadang-kadang terlalu kecil untuk dipertunjukan di kelas yang besar.

2) Gambar mati adalah gambar dua dimensi. Untuk menujukkan dimensi yang ketiga (ke dalam benda), harus di gunakan satu seri gambar dari objek yang sama tetapi dari sisi yang berbeda.

3) Tidak dapat menujukkan gerak.
4) Anak tidak selalu "membaca" (menginterprestasikan) gambar (Hastuti, 1996:178)

\subsection{Ciri-ciri Karangan Narasi}

Menurut Sujanto (1988:3), ciri utama narasi adalah gerak atau perubahan dari keadaan suatu waktu menjadi keadaan yang lain pada waktu berikutnya melalui peristiwa-peristiwa yang berangkaian. Nursisto (1999:32) menyatakan bahwa citi-ciri narasi adalah (1) narasumber dari fakta atau sekadar fiksi, (2) berupa rangkaian peristiwa, dan (3) bersifat menceritakan.

Ciri-ciri karangan narasi menceritakan sebuah rangkain peristiwa yang bersumber dari fakta atau sekadar fiksi yang bersifat menceritakan menurut urutan waktu secara kronologis (Nursisto, 1999:32).

Berdasarkan pendapat kedua ahli tersebut, dapat disimpulkan bahwa ciri-ciri karangan narasi yaitu: (1) berupa rangkaian peristiwa atau kejadian, (2) latar yang berupa latar waktu dan tempat kejadiannya peristiwa, (3) ada pelaku atautokoh yang mengalami peristiwa, (4) menekankan susunan konologis, dan (5) alasan atau latar belakang pelaku mengalami peristiwa. 


\subsection{Struktur Narasi}

Menurut Keraf (1994:147),

struktur narasi dapat dilihat dari komponen-komponen yang membentuk, yaitu alur (plot), perbuatan, penokohan, latar, dan sudut pandang. Alur merupakan kerangka dasar yang paling penting dalam kisah. Alur mengatur bagaimana tokoh-tokoh harus digambarkan dan berperan dalam tindakan-tindakan itu, dan bagaimana situasi dan perasaan karakter (tokoh) yang terlibat dalam tindakan itu yang terkait dalam satu kesatuan waktu. Oleh karena itu, baik tidaknya pengarapan sebuah plot dapat dinilai dari beberapa hal, misalnya apakah tiap insiden sudah cukup terbayang dan dimatangkan dalam insiden sebelumnya, atau apakah insiden terjadi secara kebetulan.

Keraf (1994:147) membatasi alur atau plot sebagai sebuah interrelasi fungsional antara unsur-unsur narasi yang timbul dari tindak-tanduk, karakter, suasana hati (pikiran), dan sudut pandang, serta ditandai oleh klimaks dalam rangkaian tindak-tanduk itu yang sekaligus menandai urutan bagian-bagian dalam keseluruhan narasi.

Tindak-tanduk perbuatan adalah satu kesatuan unsur dalam alur. Dalam narasi, tiap tindakan harus diungkapkan secara rinci dalam komponen-komponennya, sehingga pembaca merasakan seolah-olah mereka sendiri yang menyaksikan itu. Setiap perbuatan atau rangkaian tindakan itu harus dijalin satu sama lain dalam suatu hubungan yang logis. Hubungan yang logis antara tindaktanduk dalam sebuah narasi akan lahir sebuah kualitas sebagai hukum sebab akibat. Perbuatan atau tindak-tanduk dalam sebuah narasi harus dapat dilihat sebagai suatu arus gerak yang berkesinambungan sepanjang waktu. Dengan demikian, rangkaian tindakan tersebut dapat dilihat sebagai rangkain adegan-adegan ataupun sebagai suatu kesatuan.

Karakter-karakter adalah tokohtokoh dalam sebuah narasi dan karakterisasi adalah cara seorang penulis menggambarkan tokohnya. Narasiyang baik akan memperhatikan masalah interrelasi antartokohtokohnya dan tindak-tanduk mereka. Wujud fisiknya, motivasinya, dan tanggapannya untuk mengungkapkan sebuah tindakan sehingga memuaskan kita dalam menampilkan seorang tokoh. Proses menampilkan dan menggambarkan tokoh-tokoh melalui karakter-karakternya itu disebut penokohan (Keraf, 1994:164).

Tindak-tanduk dalam sebuah narasi biasanya berlangsung dengan 
mengambil sebuah tempat tertentu yang digunakan sebagai pentas. Tempat atau pentas itu disebut latar atau seting (Keraf, 1994:148). Latar dapat menjadi unsur yang penting dalam kaitanya dengan tindak-tanduk yang terjadi atau hanya berperan sebagai unsur tambahan.

Peran sudut pandang sangat penting sebagai teknik untuk menggarap sebuah narasi. Sudut pandang dalam narasi mempersoalkan bagaimana pertalian antara seorang yang mengisahkan narasi itu dengan tindak-tanduk yang berlangsung dengan kisah itu.

Tujuan sudut pandang adalah sebagai suatu pedoman atau tindaktanduk karakter dalam sebuah pengisahan. Orang yang membawakan pengisahan itu dapat bertindak sebagai pengamat saja, atau sebagai peserta terhadap seluruh tindak-tanduk yang dikisahkan.

Berdasarkan uraian tentang struktur narasi, dapat disimpulkan bahwa struktur narasi terdiri dari komponen-komponen pembentuknya, yaitu alur, latar/seting, penokohan, konflik, dan urutan peristiwa.

\subsection{Langkah-langkah Menulis Narasi}

Nursisto (1999:51--58) mengemukakan beberapa langkah yang harus ditempuh dalam menulis karangan narasi menulis yaitu sebagai berikut: (1) menentukan topik, sebelum mengarang kita harus menentukan topik atau tema, (2) menentukan tujuan, tujuan menulis adalah sesuatu yang ingin dicapai penulis melalui karangan yang ditulisnya, (3) mengumpulkan bahan data sangat diperlukan sebagai bahan untuk mengembangkan gagasan yang ada dalam sebuah karangan, menyusun kerangka, kerangka karangan merupakan rencana kerja yang memuat garis-garis besar atau susunan pokok pembicaraan sebuah karangan yang akan ditulis, (5) mengembangkan kerangka, pengembangan kerangka adalah menguraikan sebuah rancangan karangan juga berarti mengisi rincian atau menjabarkan uaraian permasalahan sehingga bagian-bagian tersebut menjadi lebih jelas, (6) koreksi dan revisi, naskah yang telah selesai ditulis hendaknya dikoreksi lagi, dan (7) menulis naskah yang sudah direvisi.

\subsection{Pengajaran Menulis Narasi dengan Media Gambar Seri Penggunaan media dan strategi} yang kuat akan menimbulkan minat dan semangat. Siswa akan lebih mudah untuk bersikap kreatif menulis sastra khususnya menulis narasi. Dengan menggunakan media gambar seri, siswa diharapkan mampu menulis narasi 
dengan urutan yang benar dan penggambaran setting/latar yang lebih baik.

Dalam penelitian tindakan kelas (PTK) ini, penulis memilih gambar seri sebagai media. Gambar seri yang dimaksud adalah gambar seri yang merupakan rangkaian gambar yang terdiri atas dua gambar atau lebih, yang merupakan satu kesatuan cerita. Suatu gambar atau seri gambar dapat dijadikan bahan penyusunan paragraf. Gambar atau gambar seri pada hakikatnya mengekspresikan suatu hal.

Guru hendaklah selektif dalam memilih gambar seri sebagai media pengajaran menulis narasi. Gambar yang salah justru akan membuat siswa salah tangkap, sehingga dapat menghasilkan hasil pengungkapan yang salah. Untuk itu guru haruslah mempertimbangkan aspek karakteristik siswa dan jenis materi yang akan diajarkan, waktu pengajaran, tujuan yang akan dicapai serta strategi penggunaan dalam proses pengajaran. Jika hal tersebut dilaksanakan maka dapat dipastikan gambar sebagai media pengajaran akan berhasil dan efektif.

Gambar seri yang digunakan untuk pengajaran manulis karangan narasi diutamakan gambar seri yang berwarna. Dengan adanya warna, siswa akanlebih tertarik secara visual. Selain itu, pengungkapan dalam bentuk katakatapun akan semakin mudah, misalnya saja pada pelukisan latar suatu taman. Dengan penggunaan gambar seri, siswa akan dituntut untuk mengungkapkan cerita dengan lebih baik dan runtut serta penggambaran latar yang lebih jelas. Selain itu, gambar seri juga akan memicu ketertarikan siswa sehingga siswa lebih termotivasi untuk menulis karangan narasi.

\section{Metode Penelitian}

\subsection{Setting Penelitian}

Subjek dalam penelitian ini adalah siswa kelas III semester 2 SDN 1 Kecamatan Wanasaba dengan jumlah siswa adalah 23 orang yang terdiri dari laki-laki 10 orang dan perempuan 13 orang. Penelitian ini dilaksanakan mulai bulan Maret dan April 2016.

\subsection{Prosedur Siklus Penelitian}

Penelitian ini adalah Penelitian Tindakan Kelas (PTK) atau Classroom Action Research dilakukan dengan tujuan memperbaiki mutu praktik pembelajaran di kelas. PTK ini dilakukan sebanyak 2 siklus. Tiap siklus terdiri atas empat tahapan, yaitu perencanan tindakan (planning), pelaksanaan tindakan (action), mengobservasi dan mengenali proses dan hasil tindakan (observation and evaluation), dan melakukan refleksi 
(reflection). Keempat tahapan tersebut merupakan satu siklus yang selalu berulang. Siklus pertama dilaksanakan pada tanggal 7 Maret 2016, sedangkan siklus kedua dilaksanakan pada tanggal 14 Maret 2016. Siklus dalam penelitian ini berakhir apabila hasil belajar siswa secara individu dapat memperoleh nilai minimal 65 dengan ketuntasan belajar $75 \%$.

\subsection{Pengumpulan Data}

\subsubsection{Teknik Tes}

Tes adalah seperangkat tugas yang harus dikerjakan atau sejumlah pertanyaan yang harus dijawab oleh peserta didik untuk mengukur tingkat pemahaman dan penguasaannya terhadap cakupan materi yang dipersyaratkan dan sesuai dengan tujuan pengajaran tertentu (Poerwanti, 2008:1--5). Tes dalam penelitian ini digunakan untuk mengukur kemampuan siswa dalam menulis karangan sederhana berupa lembar kerja siswa.

\subsubsection{Observasi}

Observasi adalah teknik
penilaian yang dilakukan oleh
pendidik dengan melakukan
mengamatan langsung dengan
menggunakan indera (Mudjito,
2009:14). Observasi digunakan
untuk mengamati aktivitas siswa
dan keterampilan guru dalam

pembelajaran menulis karangan sederhana bahasa Indonesia dengan media gambar berseri. Lembar instrumen keterampilan guru dan pengamatan aktivitas siswa digunakan saat pembelajaran berlangsung.

\subsubsection{Dokumentasi}

Dokumentasi adalah himpunan pertanyaan yang harus dijawab, pertanyaan-pertanyaan yang harus dipilih atau ditanggapi atau tugas-tugas yang harus dilakukan oleh peserta tes dengan tujuan untuk mengukur suatu aspek tertentu dari peserta tes (Poerwanti, 2008:3--4). Dokumentasi digunakan untuk memperoleh daftar nama siswa yang akan menjadi subjek penelitian dan memperoleh data nilai awal siswa sebelum dilakukan PTK.

\subsection{Metode Analisis Data}

Penelitian ini bersifat deskriptif yang berarti hanya memaparkan data yang diperoleh melalui lembar kerja, observasi, dan tes hasil belajar setiap siklus. Data yang diperoleh melalui observasi dan tes hasil belajar menggunakan statistik deskriptif, yaitu statistik yang berfungsi untuk menggambarkan tentang suatu keadaan. 
4. Pembahasan

\subsection{Hasil Penelitian}

\subsubsection{Pelaksanaan Siklus I}

Pembelajaran siklus I
2016, pukul 08.05--10.10 wita. Secara lengkap hasil perbaikan pembelajaran siklus I dapat dilihat pada tabel berikut. dilaksanakan pada hari Senin, 07 Maret

Tabel 4.1 Hasil Perbaikan Pembelajaran Siklus I

\begin{tabular}{|c|c|c|c|c|}
\hline No & Nama & $\begin{array}{l}\text { Nilai } \\
\text { Ketuntasan }\end{array}$ & Tuntas & Belum Tuntas \\
\hline 1 & Ahmad Jefri Majdi & 85 & $\sqrt{ }$ & \\
\hline 2 & Baiq Lina Juniarti Putri & 75 & $\sqrt{ }$ & \\
\hline 3 & Baiq Malfaliya Suryadi & 75 & $\sqrt{ }$ & \\
\hline 4 & Cantika Sinta Dewi & 85 & $\sqrt{ }$ & \\
\hline 5 & Deni Yulistiana & 80 & $\sqrt{ }$ & \\
\hline 6 & Dody Setiawan & 60 & & $\sqrt{ }$ \\
\hline 7 & Hasanatul Adawiyah & 75 & $\sqrt{ }$ & \\
\hline 8 & Huswatul Hasanah & 70 & & $\sqrt{ }$ \\
\hline 9 & L.M.Anas Marsa Pathin Zaen & 80 & $\sqrt{ }$ & \\
\hline 10 & Lalu Taofiqurrahman Hasan & 80 & $\sqrt{ }$ & \\
\hline 11 & M. Rafly Budiarrahman & 60 & & $\sqrt{ }$ \\
\hline 12 & M.Hirsan Ali Akbar & 75 & $\sqrt{ }$ & \\
\hline 13 & Mahendra Panji Buana & 60 & & $\sqrt{ }$ \\
\hline 14 & Maulia Etika Hardi & 80 & $\sqrt{ }$ & \\
\hline 15 & Mir'atul Hayati & 70 & & $\sqrt{ }$ \\
\hline 16 & Neni Arianti Ikhsan & 75 & $\sqrt{ }$ & \\
\hline 17 & Pahriadi & 65 & & $\sqrt{ }$ \\
\hline 18 & Pityatul Haerani & 90 & $\sqrt{ }$ & \\
\hline 19 & Siska Diva Safitri & 80 & $\sqrt{ }$ & \\
\hline 20 & Syifa'urrahmi Ramadhani & 70 & & $\sqrt{ }$ \\
\hline 21 & Wahyu Septiaji Apandi & 75 & $\sqrt{ }$ & \\
\hline 22 & Yek Albi Adistian & 75 & $\sqrt{ }$ & \\
\hline 23 & Yuni Andria & 80 & $\sqrt{ }$ & \\
\hline & Jumlah Nilai & 1720 & & \\
\hline & Nilai Rata-rata & 74.78 & & \\
\hline & Nilai Terendah & 60 & & \\
\hline & Nilai Tertinggi & 90 & & \\
\hline & Nilai Tuntas & $70 \%$ & 16 & \\
\hline & Nilai Belum Tuntas & $30 \%$ & & 7 \\
\hline & KKM & 75 & & \\
\hline
\end{tabular}


Tabel 4.2 Indikator Hasil Belajar Siklus I

\begin{tabular}{clc}
\hline No & \multicolumn{1}{c}{ Indikator } & Keterangan \\
\hline 1 & Nilai terendah & 60 \\
\hline 2 & Nilai tertinggi & 90 \\
\hline 3 & Jumlah Nilai & 1720 \\
\hline 4 & Nilai Rata-rata & 74.78 \\
\hline 5 & Banyaknya siswa dengan nilai $>75$ & 16 \\
\hline 6 & Banyaknya siswa dengan nilai $<75$ & 7 \\
\hline 7 & Prosentase siswa dengan nilai $>75$ & $70 \%$ \\
\hline 8 & Prosentase siswa dengan nilai $<75$ & $30 \%$ \\
\hline
\end{tabular}

Tabel di atas menunjukkan ada 16 siswa yang mendapat nilai $75 \mathrm{ke}$ atas dan 7 siswa nilainya di bawah 75. Jika diperinci hasil evaluasi perbaikan pembelajaran siklus I seperti pada tabel berikut.

Tabel 4.3 Prosentase Hasil Evaluasi Perbaikan Pembelajaran Siklus I

\begin{tabular}{llcc}
\hline No & Rentang Nilai & Jumlah Siswa & Prosentase \\
\hline 1 & $0-10$ & - & - \\
\hline 2 & $11-20$ & - & - \\
\hline 3 & $21-30$ & - & - \\
\hline 4 & $31-40$ & - & - \\
\hline 5 & $41-50$ & - & - \\
\hline 6 & $51-60$ & 3 & $13 \%$ \\
\hline 7 & $61-70$ & 4 & $17 \%$ \\
\hline 8 & $71-80$ & 13 & $57 \%$ \\
\hline 9 & $81-90$ & 3 & $13 \%$ \\
\hline 10 & $91-100$ & - & - \\
\hline & Jumlah & 23 & $100 \%$ \\
\hline
\end{tabular}

Dari tabel di atas, terlihat hasil evaluasi perbaikan pembelajaran siklus I, bahwa dari 23 siswa, nilai 51 sampai dengan 60 sebanyak 3 siswa, nilai 61 sampai dengan 70 sebanyak 4 siswa, nilai 71 sampai dengan 80 sebanyak 13 siswa, nilai 81 sampai dengan 90 sebanyak 3 siswa, dan tidak ada sorangpun yang mendapat nilai 91 sampai dengan 100.

Apabila hasil evaluasi perbaikan pembelajaran siklus I mata pelajaran bahasa Indonesia materi menulis karangan narasi kelas III semester 2 di SDN 1 Wanasaba jika disajikan dalam bentuk diagram maka akan terlihat seperti diagram di bawah ini. 


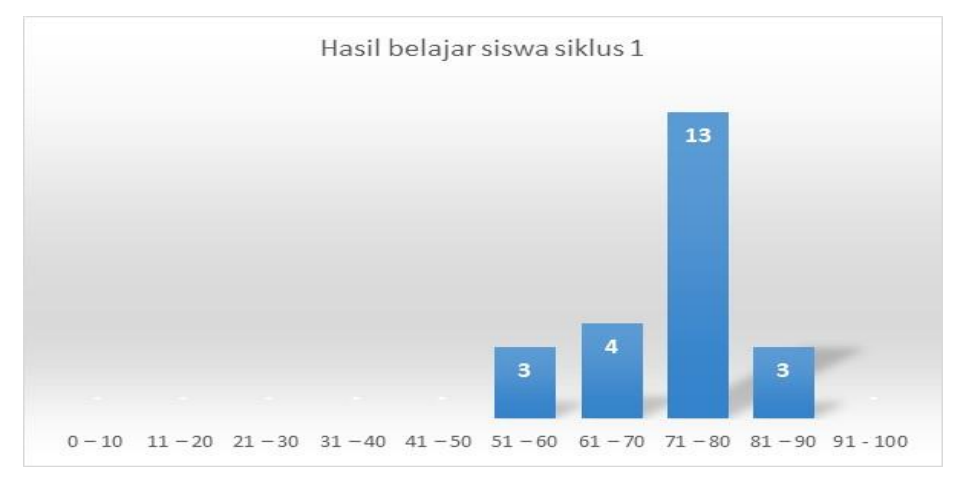

Diagram 4.4 Hasil Evaluasi Perbaikan Pembelajaran Siklus I

Dari analisis hasil tes formatif siklus I dan gambar grafik di atas nilai rata-rata kelas pembelajaran bahasa Indonesia tentang menulis karangan narasi adalah 74,78. Siswa yang belum tuntas dalam pembelajaran sebanyak 7 siswa (30\%) dan yang tuntas ada 16 siswa dengan prosentase ketuntasan belajar baru mencapai $70 \%$.

Hal ini menunjukkan bahwa hasil prestasi siswa sudah ada kemajuan atau peningkatan, akan tetapi masih perlu ditingkatkan agar siswa dapat menguasai materi pelajaran bahasa Indonesia tentang menulis karangan narasi yang diajarkan oleh guru. Dalam hal ini, peneliti masih perlu segera mengambil langkah untuk memperbaiki pembelajaran tersebut agar siswa dapat memahami materi sesuai dengan kompetensi yang harus dicapai dalam pembelajaran.

\subsubsection{Pelaksanaan Siklus II}

Perbaikan pembelajaran siklus II dilaksanakan pada hari Senin, 14 Maret 2016, pukul 08.05--10.10 wita dengan objek penelitian adalah siswa kelas III SDN 1 Wanasaba. Dengan dibantu teman sejawat yang bertindak sebagai observer sesuai dengan rencana. Skenario pembelajaran berlangsung dengan baik. Pada akhir pembelajaran, peneliti mengadakan evaluasi hasil belajar untuk mengetahui tingkat keberhasilan. Hasil perbaikan pembelajaran disajikan pada tabel sebagai berikut.

Tabel 4.5 Hasil Perbaikan Pembelajaran Siklus II

\begin{tabular}{clccc}
\hline No & \multicolumn{1}{c}{ Nama } & Nilai & Tuntas & Belum Tuntas \\
1 & Ahmad Jefri Majdi & 90 & $\sqrt{ }$ & \\
2 & Baiq Lina Juniarti Putri & 75 & $\sqrt{ }$ & \\
\hline
\end{tabular}




\begin{tabular}{|c|c|c|c|c|}
\hline No & Nama & $\begin{array}{c}\text { Nilai } \\
\text { Ketuntasan }\end{array}$ & Tuntas & Belum Tuntas \\
\hline 3 & Baiq Malfaliya Suryadi & 80 & $\sqrt{ }$ & \\
\hline 4 & Cantika Sinta Dewi & 80 & $\sqrt{ }$ & \\
\hline 5 & Deni Yulistiana & 80 & $\sqrt{ }$ & \\
\hline 6 & Dody Setiawan & 75 & $\sqrt{ }$ & \\
\hline 7 & Hasanatul Adawiyah & 75 & $\sqrt{ }$ & \\
\hline 8 & Huswatul Hasanah & 80 & $\sqrt{ }$ & \\
\hline 9 & $\begin{array}{l}\text { L.M. Anas Marsa Pathin } \\
\text { Zaen }\end{array}$ & 80 & $\sqrt{ }$ & \\
\hline 10 & Lalu Taofiqurrahman Hasan & 90 & $\sqrt{ }$ & \\
\hline 11 & M. Rafly Budiarrahman & 85 & $\sqrt{ }$ & \\
\hline 12 & M.Hirsan Ali Akbar & 75 & $\sqrt{ }$ & \\
\hline 13 & Mahendra Panji Buana & 85 & $\sqrt{ }$ & \\
\hline 14 & Maulia Etika Hardi & 85 & $\sqrt{ }$ & \\
\hline 15 & Mir'atul Hayati & 85 & $\sqrt{ }$ & \\
\hline 16 & Neni Arianti Ikhsan & 90 & $\sqrt{ }$ & \\
\hline 17 & Pahriadi & 75 & $\sqrt{ }$ & \\
\hline 18 & Pityatul Haerani & 95 & $\sqrt{ }$ & \\
\hline 19 & Siska Diva Safitri & 80 & $\sqrt{ }$ & \\
\hline 20 & Syifa'urrahmi Ramadhani & 75 & $\sqrt{ }$ & \\
\hline 21 & Wahyu Septiaji Apandi & 80 & $\sqrt{ }$ & \\
\hline 22 & Yek Albi Adistian & 75 & $\sqrt{ }$ & \\
\hline \multirow[t]{8}{*}{23} & Yuni Andria & 90 & $\sqrt{ }$ & \\
\hline & Jumlah Nilai & 1880 & & \\
\hline & Nilai Rata-rata & 81.74 & & \\
\hline & Nilai Terendah & 75 & & \\
\hline & Nilai Tertinggi & 95 & & \\
\hline & Nilai Tuntas & $100 \%$ & 23 & \\
\hline & Nilai Belum Tuntas & $0 \%$ & & \\
\hline & KKM & 75 & & \\
\hline
\end{tabular}

Tabel 4.6 Hasil Evaluasi Perbaikan Pembelajaran Siklus II

\begin{tabular}{lll}
\hline No & Indikator & Keterangan \\
\hline 1 & Nilai terendah & 75 \\
\hline 2 & Nilai tertinggi & 95 \\
\hline 3 & Jumlah Nilai & 1880 \\
\hline 4 & Nilai Rata-rata & 81.74 \\
\hline 5 & Banyaknya siswa dengan nilai $>75$ & 23 \\
\hline 6 & Banyaknya siswa dengan nilai $<75$ & 0 \\
\hline 7 & Prosentase siswa dengan nilai $>75$ & $100 \%$ \\
\hline 8 & Prosentase siswa dengan nilai $<75$ & $0 \%$ \\
\hline
\end{tabular}

Pembelajaran bahasa meningkatkan nilai siswa dalam Indonesia pada siklus II dapat menulis karangan narasi dengan 
memuaskan. Semua siswa tuntas belajar dengan nilai 75 ke atas. Setelah melalui kegiatan perbaikan, pembelajaran siklus II maka hasil tes formatif mata pelajaran bahasa Indonesia pada akhir siklus II mengalami peningkatan yang signifikan.

Jika diperinci hasil evaluasi perbaikan pembelajaran siklus II seperti pada tabel sebagai berikut.

Tabel 4.7 Prosentase Hasil Evaluasi Perbaikan Pembelajaran Siklus II

\begin{tabular}{clcc}
\hline No & Rentang Nilai & Jumlah Siswa & Persentase \\
\hline 1 & $0--10$ & - & - \\
\hline 2 & $11--20$ & - & - \\
\hline 3 & $21--30$ & - & - \\
\hline 4 & $31--40$ & - & - \\
\hline 5 & $41--50$ & - & - \\
\hline 6 & $51--60$ & - & - \\
\hline 7 & $61--70$ & - & - \\
\hline 8 & $71--80$ & 14 & $61 \%$ \\
\hline 9 & $81--90$ & 8 & $35 \%$ \\
\hline 10 & $91--100$ & 1 & $4 \%$ \\
\hline & Jumlah & 23 & $100 \%$ \\
\hline
\end{tabular}

Dari tabel di atas, dapat dilihat hasil evaluasi perbaikan pembelajaran siklus II, bahwa dari 23 siswa tidak seorangpun yang mendapat nilai 31 sampai dengan 70, nilai 71 sampai dengan 80 sebanyak 14 siswa, nilai 81 sampai dengan 90 sebanyak 8 siswa, nilai 91 sampai dengan 100 sebanyak 1 siswa.
Apabila hasil evaluasi perbaikan pembelajaran siklus II mata pelajaran bahasa Indonesia dengan materi menulis karangan narasi kelas III semeter 2 di SDN 1 Wanasaba pada akhir kegiatan perbaikan pembelajaran siklus II disajikan dalam bentuk diagram maka akan terlihat seperti grafik di bawah ini. 


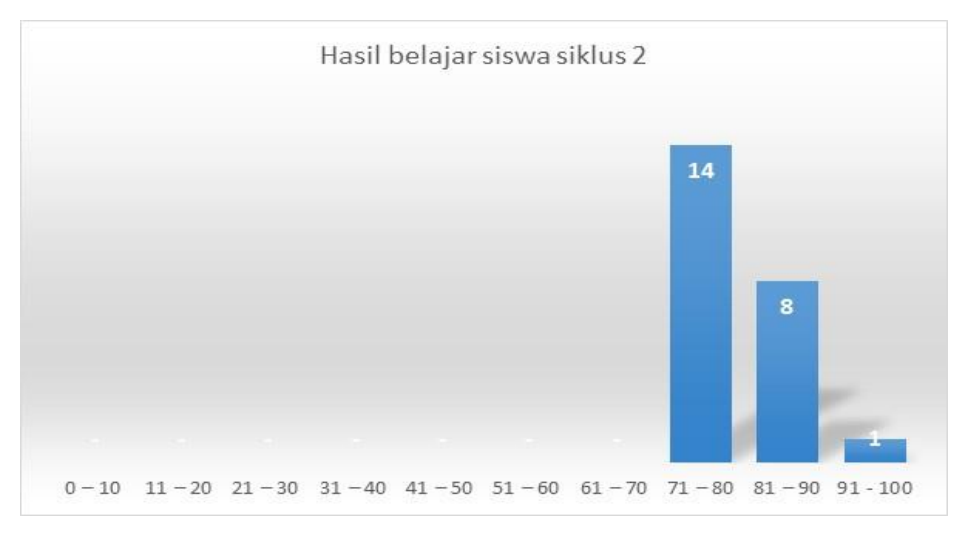

Diagram 4.8 Hasil Evaluasi Perbaikan Pembelajaran Siklus II

Dari analisis hasil tes formatif siklus II dan gambar diagram di atas dalam pembelajaran bahasa Indonesia tentang menulis karangan narasi, nilai rata-rata kelas 81,74 . Siswa yang tuntas 23 siswa dengan persentase ketuntasan belajar $100 \%$. Hal ini menunjukkan bahwa yang dilakukan oleh guru sudah berhasil meningkatkan prestasi siswa sesuai

Tabel 4.9 Peningkatan Ketuntasan Hasil Belajar dan Nilai Rata-rata

\begin{tabular}{llccccccc}
\hline \multirow{2}{*}{ NO. } & Kriteria & \multicolumn{2}{c}{ Pra Siklus } & \multicolumn{2}{c}{ Siklus I } & \multicolumn{2}{c}{ Siklus II } \\
\cline { 2 - 10 } & $\begin{array}{c}\text { Jumlah } \\
\text { Siswa }\end{array}$ & $\%$ & $\begin{array}{c}\text { Jumlah } \\
\text { Siswa }\end{array}$ & $\%$ & $\begin{array}{c}\text { Jumlah } \\
\text { Siswa }\end{array}$ & $\%$ \\
\hline 1 & Tuntas & 6 & $26 \%$ & 16 & $70 \%$ & 23 & $100 \%$ \\
\hline 2 & Belum Tuntas & 17 & $74 \%$ & 7 & $30 \%$ & 0 & $0 \%$ \\
\hline 3 & Rata-Rata & \multicolumn{2}{c}{56.13} & \multicolumn{2}{c}{74.78} & & 81.74 & \\
\hline
\end{tabular}

Dari tabel di atas, siswa yang nilainya 75 ke atas pada evaluasi sebelum perbaikan pembelajaran ada 6 siswa dari 23 siswa atau $26 \%$. Pada perbaikan pembelajaran siklus I terjadi peningkatan. Siswa yang mendapat nilai 75 ke atas menjadi 16 siswa atau $70 \%$ dan pada dengan hasil yang diharapkan dalam menguasai materi pembelajaran ahasa Indonesia tentang menulis karangan narasi. Setelah kedua siklus perbaikan pembelajaran dilaksanakan terdapat kemajuan yang semakin meningkat. Tingkat kemajuan tersebut dapat dilihat pada tabel berikut ini. 
II nilai rata-ratanya adalah 81,74 dan pada siklus II tidak diadakan perbaikan atau dilanjutkan ke siklus III karena semua siswa sudah tuntas.
Apabila ketuntasan hasil belajar disajikan dalam bentuk diagram, maka akan dapat dilihat pada diagram berikut ini.

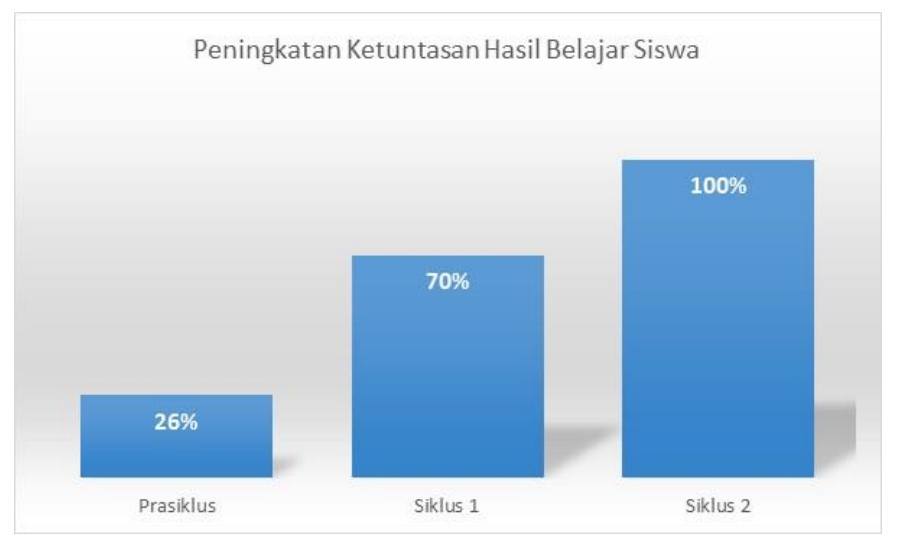

Diagram 4.10 Peningkatan Ketuntasan

Diagram di atas menunjukkan peningkatan prosentase ketuntasan dari prasiklus, siklus I dan siklus II mata pelajaran bahasa Indonesia kelas III semester 2 SDN 1 Wanasaba dengan materi menulis karangan narasi. Sebelum perbaikan pembelajaran (prasiklus), prosentase ketuntasannya $26 \%$. Pada siklus I yaitu $70 \%$ dan siklus II adalah $100 \%$.

\section{Kenaikan} persentase ketuntasan dari prasiklus ke siklus I yaitu $44 \%$ dan dari siklus 1 ke siklus II adalah 30\%. Dengan demikian, peningkatan prosentase ketuntasan dari sebelum diadakan perbaikan pembelajaran sampai dengan setelah diadakan perbaikan adalah $74 \%$.

Hasil belajar dari tahapan prasiklus sampai siklus II peningkatan nilai rata-rata dari sebelum perbaikan atau prasiklus sampai siklus II, jika disajikan dalam bentuk diagram batang dapat dilihat sebagai berikut. 
Diagram 4.11 Peningkatan nilai rata-rata dari Prasiklus sampai Siklus II

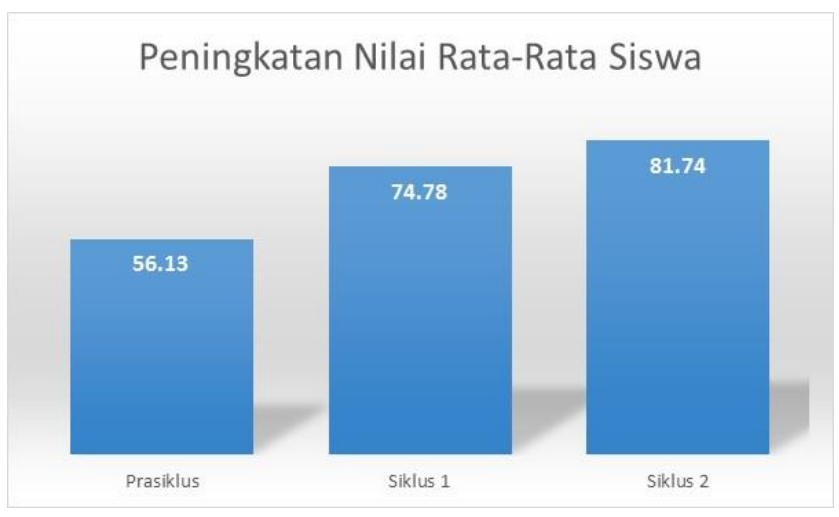

Diagram di atas menunjukkan peningkatan rata-rata nilai hasil evaluasi dari pra siklus, siklus I dan siklus II mata pelajaran bahasa Indonesia kelas III semester 2 SDN 1 Wanasaba dengan materi menulis karangan narasi. Sebelum perbaikan pembelajaran (prasiklus) nilai rataratanya 54,13. Pada siklus I nilai rata-ratanya 74,78 dan siklus II nilai rata-ratanya 81,74 . Kenaikan nilai rata-rata dari prasiklus ke siklus I yaitu 18.85 dan dari siklus 1 ke siklus II adalah 6,96. Dengan demikian, peningkatan nilai ratarata dari sebelum diadakan perbaikan pembelajaran sampai dengan setelah diadakan perbaikan adalah 25,61.

\section{Penutup}

Berdasarkan hasil peneltian dan pembahasan pada bab sebelumnya, penelitian ini dapat disimpulkan sebagai berikut:

a. Keterampilan menulis karangan narasi siswa kelas III Semester II SDN 1 Wanasaba Tahun Pelajaran 2015/2016 sebelum melaksanakan proses perbaikan pembelajaran dari 23 orang, siswa yang mendapat nilai 75 keatas hanya 6 orang (26\%). Setelah dilakukan perbaikan, pembelajaran pada siklus 1 siswa yang mendapat nilai $75 \mathrm{ke}$ atas meningkat menjadi 16 Orang (70\%) dan siklus 2 mencapai 23 orang (100\%).

b. Pembelajaran menggunakan media gambar seri sangat efektif dalam meningkatkan keterampilan menulis karangan narasi siswa kelas III Semester II SDN 1 Wanasaba Tahun Pelajaran 2015/2016. Hal dibuktikan dengan motivasi dan antusias siswa dalam mengikuti pembelajaran sangat baik.

c. Peningkatan keterampilan menulis karangan narasi siswa kelas III Semester II SDN 1 Wanasaba Tahun Pelajaran 
2015/2016sangat signifikan. Hal ini dibuktikan dengan ketuntasan belajar siswa dan nilai rata-rata mengalami peningkatan setelah dilaksanakan perbaikan pembelajaran. Nilai rata-rata sebelum dilakukan perbaikan adalah 56,13 setelah dilakukan perbaikan pada siklus I yaitu 74.78, sedangkan pada siklus II nilaiya menjadi 81,74.

\section{Daftar Pustaka}

Ahkadiah, S., dkk. (2003). Pembinaan Kemampuan Menulis Bahasa Indonesia. Jakarta: Erlangga.

Angkoso, Robertes dan Kosasih, A. (2007). Optimalisasi Media Pembelajaran. Jakarta: Grasindo

Djamarah, (2002). Prestasi Belajar dan Kompetensi Guru. Surabaya: Usaha Nasional.

Djamarah, Syaiful Bahri dan Zain, Aswan. (2010). Strategi Belajar Mengajar. Jakarta: Rineka Cipta.

Hastuti, Sri. (1996). Strategi Belajar Mengajar Bahasa Indonesia. Jakarta: Depdikbud

Keraf, Gorys. (1983). Argumentasi dan Narasi. Jakarta: Gramedia.

Keraf, Gorys. (1995). Eksposisi. Jakarta: Gramedia.

Nursisto. (1999). Penuntun Mengarang. Yogyakarta: Adicita.

Parera, Jos Daniel. (1993). Menulis Tertib dan Sistematik. Jakarta: Erlangga.
Sujanto. (1988). "Keterampilan Menulis Karangan Narasi dengan Teknik Modeling pada Siswa Kelas 11 D SLTP Sukorejo Kendal 2003/2004”. Semarang.

http://www.sekolahdasar.net/2011/11/pemb elajaran-menulis-di-sd.htmldiakses tanggal 15 Oktober 2016, pukul 17.00 